\title{
The curse of poverty and marginalisation in language development: The case of Khoisan languages of Botswana
}

\author{
Andy Chebanne \\ Faculty of Humanities, University of Botswana, Botswana \\ E-mail: chebanne@ub.ac.bw
}

Mawande Dlali

Department of African Languages, University of Stellenbosch, South Africa

E-mail:mdl@sun.ac.za

\begin{abstract}
Khoisan languages are spoken by tiny and remote-dwelling communities of Botswana, the members of which are characterised by socio-economic hardships and illiteracy in their own languages and in general. Historically and socially, these people emerged from a life of hunting and gathering, and, in that lifestyle mode, they were easily subdued and exploited by other language communities for cheap and serf labour. Colonialism found them in this social state, and post-colonialism has left them in the same state. As poor and marginalised subalterns, they have not had any means to advocate for their language and culture, and are currently assimilated into other peoples' languages and cultures. Consequently, the remaining languages of these communities, spoken in remote areas by poor people, are threatened with extinction because they remain under-developed, under-documented, and are at best still at the stage of documentation by anthropologists and linguists. As illiterate people, the speakers of these Khoisan languages have no survival strategies for their languages in this ever-evolving, modern world. With their poverty and sociolinguistic marginalisation, they are devoid of any means of promoting their languages. This discussion focuses on the pitiful situation of the Khoisan languages of Botswana. Botswana's language-use policy will be critically examined and characterised as one factor in the marginalisation and disempowerment of minority groups, both of which lead to the languages' endangerment and death.
\end{abstract}

Keywords: Khoisan; marginalised languages; language policy; endangered languages; language literacy; promotion; revitalisation.

\section{Introduction}

The definition and understanding of "the Khoisan" adopted in this discussion is based on Güldenmann (2014), whose research has provided a comprehensive inventory of this people, 
and also provided a universal acceptance of the appropriate terminologies by which these speech communities should be called. His classification of Khoisan further helps to understand their inter-ethnic relationships (Güldenmann 2014: 27). The Khoisan sociolinguistic and sociocultural conditions are succinctly captured by Brenzinger (2003), whose research has contributed to a clearer understanding of Khoisan communities in contact situations. In these socio-political and socio-economic situations of poverty and powerlessness, Khoisan communities do not have the means to organise the promotion of their languages and cultures (Chebanne 2015). Botswana, a middle-income African country, is not exempt from these hindrances, and this country is often mistakenly construed as a homogenous society with a population experiencing less social and economic challenges (Cassidy, Good, Mazonde, and Rivers 2001; Saugestad 2001). According to the Botswana Core Welfare Indicators Survey (2009/2010), the proportion of individuals who were living below Botswana's Poverty Datum Line (PDL) decreased from $30,6 \%$ in $2002 / 2003$ to $19,3 \%$ in $2009 / 2010$. The proportion of those living in abject poverty or below US\$1.25 per day decreased from $23,4 \%$ in $2002 / 2003$ to $6,4 \%$ during the same period. Whilst these statistics demonstrate good progress, these levels are still relatively high and need to be reduced substantially, according to the Botswana National Development Plan (Botswana Government 2016: 20). This misconception of prosperity resulted from two factors: firstly, during the colonial period, recognition of ethnic communities was based on whether or not they had a central authority and territory. Most of the government activities were therefore cantered on the areas and the people who mattered in local politics. The colonial government, therefore, was more directly involved with Tswana chiefs in their governance, and assumed no other ethnic groups had critical recognition (Solway 2002). The Khoisan were some of these overlooked populations, and they remain so. Wherever they were found, they were assumed to be subjects of the Tswana chiefs (Saugestad 2001). Secondly, the subjugation of non-Tswana tribes, such as the Khoisan, resulted in the spread of the Setswana language and culture across the whole territory, and because it was assumed that everyone could speak Setswana, suppression of other languages and cultures with deliberate assimilation policies were perceived as good strategies of nation building (Batibo 2010).

In official discourse, non-Tswana-speaking groups are referred to by the name of the Tswana groups that subjected them to quasi slavery before and during the colonial period (Chebanne and Nyati-Ramahobo 2003-2004). Subsuming Khoisan communities under the Tswana groups covers underlying cultural and linguistic discrimination, and legitimises ethnic domination, as the following observation from UNESCO World Commission on Culture and Development (1995: 57) illustrates:

Minorities often find it difficult to participate fully in the activities of societies that favour dominant groups. Sometimes this discrimination is embedded in the legal framework that denies these minorities access to education, employment and political representation. More generally, however, the lack of participation is less a matter of official policy than of everyday practice. The challenge consists in first removing discriminatory barriers and then creating the basis for the empowerment of these minorities.

Therefore, when the Khoisan are regarded as poor, this poverty is material and moral. They own no land, they have no tribal authority or territory, and no culture of their own to promote or enjoy (Cassidy et al. 2001). While there is adequate coverage in the linguistic study of Khoisan languages of southern Africa, the specific ethnic composition of the Khoisan in Botswana is either 
not known or is ignored in official discourse. It is therefore important to reiterate that these languages consist of three families - Kx'a, Tuu, and Khoe-Kwadi - all of which exist in Botswana. Importantly, it should be clarified that "San" is not a linguistic unit, however, all Khoe speakers in Botswana are San (Güldemann 2014). The common socio-economic condition of the San in Botswana is captured in the following quotation by Cassidy et al. (2001: 7):

\begin{abstract}
Botswana's San population is comprised of a number of distinct language groups. Their undifferentiated inclusion under the labels 'Basarwa', 'San' or 'Bushmen' belies both the linguistic and cultural diversity of these people. Despite this, Botswana's San communities have much in common that marks them as distinct from the country's other rural poor.
\end{abstract}

There are very scant reports of the San languages' sociolinguistic dynamics, and of the ways in which they are losing their languages at an alarming rate (Chebanne 2002). Also, the apparent situation of social and cultural marginalisation of these languages does not arouse much in the way of policy considerations at the level of the State. Hegemony of linguistic and cultural nature is fostered in Botswana (Nyati-Ramahobo 1999). What is also important to consider in these issues of the sociolinguistic domination and impoverishment of the San is what Chebanne (2002, 2003) qualified as their "autochthony" or "aboriginality". The situation puts them in a condition so that they are now considered "primitive" in official discourse, and needing to be developed in order to join the mainline society (Saugestad 2001). Historically, the Khoisan lived in small, closely-related groups, and this social and demographic characteristic became a political disadvantage. The Bantu - a mixed, farming group - quickly invaded the land of the Khoisan, and subjugated the people. The Khoisan are therefore subalterns in the land that used to be theirs (Barnard 1988).

The provisions of the Botswana administrative and official languages practice (cf. Article 60 (d) of the Constitution), constitutional articles 77 and 78, and various official pronouncements on language policy (cf. NDP 7) effectively declare Botswana indigenously and linguistically a mono-ethnic country. In its homogeneity, Setswana takes the status and the role of the sole national language, while English takes, both internally and internationally, the prestigious position as an official language. Associated with those constitutional pronouncements and privileges are the beliefs and practices that Botswana is a nation made up of only Tswana tribes or ethnic groups. Only the Setswana-speaking ethnic groups have ex-officio representation in the House of Chiefs (cf. the Chieftainship Act). These policy provisions legitimise ethnic and linguistic marginalisation (Nyati-Ramahobo 2002). The consequences of this marginalisation in Africa are, as Brenzinger (2003: 60) states, "marginalization in socio-economic, political and cultural respects, i.e. the denial of access to development is the prevailing factor reducing the number of African languages".

The situation that these communities find themselves in in Botswana is eloquently accounted for by Saugestadt (2001), who describes as "inconvenient[ly] indigenous" the relationship between the State and the autochthonous minorities who, under the State's guise of linguistic and cultural neutrality and homogeneity, are silenced and brought under other tribal hegemonies of recognised tribal communities (Mphinyane 2002). The following social situations, as noted by Cassidy et al. (2001: 2), help to account for how these communities remain in powerlessness: 
Special features of Botswana's democracy appear to impact negatively upon the San $[\ldots]$ public discussion of the problems of the San hardly occurs [...] San poverty and ethnic marginalization are problems, but they have yet to become issues of public debate and decision-making.

This discussion uses findings from various studies over 20 years to tackle the seemingly-helpless situation of the Khoisan languages in Botswana; the terms "San" and "Khoisan" are used interchangeably. It will argue that Botswanan social policies and the language-use policy in education are factors in the marginalisation of Khoisan populations and their linguistic endangerment. When these Khoisan populations are reduced to poor and marginalised subalterns, they have no capacity to advocate for their language and culture revitalisation through education.

\section{Powerlessness and poverty of the Khoisan}

Even in their diversity within Botswana, Khoisan communities can best be qualified as powerless and poor. Several factors account for the Khoisan's lack of power to advance themselves, both socially and economically, as a distinct group (Jeffris 1997). Research by Cassidy et al. (2001) shows how the Khoisan are now living in abject and desperate conditions in which they cannot redeem themselves from their necessitous existence, and the desperation of their culture and languages (Batibo 2010). The following excerpt from (Cassidy et al. 2001: 11) illustrates this powerlessness and abject poverty:

In Botswana there are substantial differences in socio-economic conditions between urban and rural areas. These are well documented and are a cause of concern for Government. As most San are rural dwellers, they tend to be poor. What is not documented, however, is that in many cases San are poorer than other rural poor. They own fewer livestock, have smaller fields, live on the outskirts of settlements and have much lower literacy rates. They do not speak at Kgotla meetings and their traditional decision-making systems have been replaced by the Tswana kosi system that was imposed as Botswana moved into the area.

This quotation is a serious indictment on Botswana's social policies of development. The persistence of the San's pitiful socio-economic situation can be accounted for by their condition of autochthony, demographic minority, and landlessness, as will be discussed in the sections below.

\subsection{Autochthony}

There are two important observations that need to be made in order to provide a clarification of the use of the term "autochthony". First, while there are Khoekhoe speakers who are/were pastoralists, it is most notable that the Nama of Namibia, the Damara, Haillom, and $\neq$ Aakhoe (all Khoehoe speakers) are foragers. All speakers of Kx'a, Tuu, and Khoe, with the exception of the aforementioned Nama, are foragers, and are therefore labelled "San" in Botswana. The autochthony is therefore used from a cultural perspective of the hunter-gatherer mode of life, and the maintenance of this distinct lifestyle (Chebanne 2003). Linguistically, (following Vossen 1998, there is (i) Khoekhoe (not found in Botswana), (ii) Western Kalahari Khoe (Khwe, Naro, Glui-Gllana), and (iii) Eastern Kalahari Khoe (Shua, Tshwa, Ts'ixa). All of the 
groups listed here are Kalahari Khoe-speaking groups found in the following regions: Central Kalahari (Glui-Gllana, Naro), Eastern Kalahari Basin fringe (Kua, Tsua), and Okavango Delta or Northern Botswana ( $\|$ Ani and Buga). Also, importantly, the Shua (Eastern Kalahari Basin fringe) is a group which should definitely be considered when discussing the question at hand, as well as the Ts'ixa, a group from the Okavango Delta which closely neighbours the Buga and $\|$ Ani. These hunter-gatherers have been systematically pushed out of their ancestral lands by Bantu agri-pastoralists (Barnard 1988; Thapelo 2002).

In the arguments made by Eide (2000), what is normally considered when distinguishing indigenous or autochthonous peoples from other groups is their prior settlement in the territory in which they live, combined with their maintenance of a separate culture which is closely linked to their particular ways of using land and natural resources (Mokhtar 1990). The Khoisan speakers are now mostly found in regions less suitable for agriculture or pastoralism (including the Okavango Delta, which is hardly a desert) due to pressure from other groups. It should be stated here for clarity that while it is true that the Khoisan are traditionally linked to survival under harsh conditions, it should not be misconstrued that they have actually adapted to the desert. Further, it should be clarified that in southern Africa the term "indigenous" poses sociopolitical problems. It should be accepted from archaeological and historical evidence that the Khoisan were in the region earlier than the Bantu population (Dowson and Lewis-Williams 1994: 5; Shillington 1989/1995). The usefulness of a clear-cut distinction between such minorities and indigenous peoples is debatable in Africa, and specifically in the socio-political context of Botswana (Chebanne 2015).

\subsection{Demographic minority}

According to Chebanne (2002), these communities would be characterised socially and linguistically as being in the minority. "Minority", in an ethnographic context, is a term that is inspired by demographic considerations of a group of people whose limited numbers are characteristic in the areas of (i) social and economic consideration of powerlessness, (ii) subordination or special influence or domination by others, (iii) occupying a less privileged territoriality, and (iv) showing some vulnerability due to lack of self-determination in matters of economic progress, linguistic, and cultural life. The ideal type of minority is therefore demographic, while the "indigenous peoples" focuses on aboriginality and certain territoriality.

\subsection{Landlessness of autochthonous San}

Khoisan communities in Botswana are essentially in a colonial situation as their territoriality, culture, and language are subsumed under the hegemony of other groups (Chebanne 2015). They do not qualify as an independent socio-cultural group with rights to live on land that could be designated as their tribal territory (Barume 2000: 21). They can only be allocated land that is under the authority and ownership of other recognised tribes (Saugestad 2001: 119, 228). Land that is occupied by communities that do not fall within what is defined by Act 2 of the Botswana Constitution is regarded as "State Land" (a sort of no-man's land). The land they claim, the Central Kalahari Game Reserve (CKGR), which is the ancestral territory of various groups speaking Khoe (Glui-Gllana), Kx'a (Jul'hoan) and Tuu (!Xoon), is now a game and tourism reserve (Saugestad 2001). The Ts'ixa and Buga are the former dwellers of Moremi and Chobe while the Shua speakers were mostly found in Nxai Pan and Makgadikgadi. Obviously, these communities are in the same situation as with the CKGR Khoisan groups but involve 
different land, game parks, and peoples. In effect, this land is considered in state policies as unoccupied or having land-use status that is inactive or untouched. The notion of 'ancestral land' or occupancy status by the Khoisan is thus deemed as inappropriately used (Silberbauer 1981; Barnard 1988). Of course, the ideal would be that the Khoisan-speaking communities are recognised politically, have access to land, healthcare, education, etc. within their self-defined ethnic categories. Without this recognition, their well-being cannot be achieved.

\section{The misunderstanding or misrepresentation of the Khoisan people}

Despite the fact that the Botswanan Constitution guarantees the personal rights and freedoms for every citizen, irrespective of one's colour, tribe, or religious affiliation (Botswana Constitution, Article II, 3), minority Khoisan ethnic groups still face a number of hurdles with regard to common rights and freedoms in the domains of ethnic identity, culture, and language. The limitations of the Constitution in respect of the provision of language and cultural policies mean that for all of these groups, their existence as ethnic entities is not recognised. This is because the Constitution and the laws of Botswana individuate the human person, and consequently do not regard an individual from an ethno-cultural perspective. No government sector takes ethnic minorities and their linguistic and cultural idiosyncrasies into account (Chebanne 2003). The effect of this is that there is an undeclared discrimination of ethnic minorities by the law (Chebanne 2002). For instance, the provisions of sections 3 and 15 of the Constitution have been deemed inadequate to fully respond to the requirements of Article 1 of the United Nations Convention on the Elimination of all forms of Racial Discrimination (cf. UN(CERD) response to Botswana 23/8/2002).

In Botswana, social policy and the bureaucracy within the post-colonial interpretation (Thapelo 2002) have been characterised by disparities between the educated and the non-educated, the rich and the poor, and the majority and minority, in the contribution to the definition of national development and its priorities. Policies have been formulated from a monolithic perspective, and completely overlook diversity and difference (Chebanne 2015). The Constitution, which in essence generalises various aspects of human rights, does not guarantee collective rights but rather individual ones (Mazonde 2002). By enshrining and entrenching colonial privileges of those who had "territorial lands rights", the Constitution effectively denies that any other community such as the San may have anything else in its own right. These concerns were also made by Silberbauer (1981), Saugestad (2001), and recently by Chebanne (2015). The constitutional provision of Article II, section 3, which claims equality, becomes a mere hackneyed chant or window dressing, while those who distinguish themselves linguistically and culturally live in a situation of denial regarding their ethnicity and the rights accruing from it (Chebanne 2002, 2010). To some analysts, the social inequality of these groups is exacerbated by the post-colonial elite's domination of the main Botswanan socio-political processes which determine participation in or exclusion from social and economic amenities, institutions, ethnocultural discourse, and the political economy (Mphinyane 2002; Thapelo 2002).

The other underlying factor in the San interaction with the main groups that control socioeconomic modes of production and socio-political policies of development is that there is no aspect in the other groups' contact with them where San communities emerge as equals or at least benefitting as people with equal rights. When anything is done for them, it further entrenches negative difference and marginalisation (Chebanne 2015). In any case, the efforts to 
bring the autochthonous San ethnic groups to the mainline national linguistic-cultural groups have effectively nothing that improves the lot of a people who are systematically dispossessed and disenfranchised by the hegemonic ethnic entities and the State (Cassidy et al. 2001; Chebanne 2015). The net effect of state policies is more about empowering the already powerful, and making the wealthy wealthier. This is a glaring example of neo-colonial economic imperialism, and a crude way of responding to a post-modernist agitation for rights (Chebanne 2015; Nyati-Ramahobo 2002).

\section{Can languages of poor and illiterate people be developed?}

The foregoing arguments lead to the question of whether poor, powerless, and illiterate Khoisan speech communities can be capable of developing their languages. Khoisan languages, it should be recalled, are spoken in remote areas by poor people. It should be clarified that there are additional reasons for language death other than under-development or under-documentation; socio-economic factors also play a big role, as does pressure from dominant groups (Batibo 2005; Cassidy et al. 2001). Khoisan communities are not only poor but also illiterate, in their own languages and in the country's official languages (Cassidy et al. 2001; Batibo 2010). This illiteracy presents serious challenges in the way they speak for themselves or are spoken for by advocacy groups (Batibo 2005, 2010; Cassidy et al. 2001). Whenever they are spoken for, their issues are hijacked by those organisations which most of the time do not appreciate the specific socio-cultural conditions in which the Khoisan communities live (Mphinyane 2002). Their recourse is not even from government policies as it is clear that what was put in place since independence was a social-policy agenda that sought to build unity by negating social and cultural diversity (Nyati-Ramahobo 1987, 2002). The conception of identity and equality based on ethnic diversity has been spurned and discredited in research on social policy (Cassidy et al. 2001; Saugestad 2001; Nyati-Ramahobo 2002; Chebanne 2015).

It is clear from research on the social processes in Botswana that members of the minority groups of this country are, in many accounts, second-class citizens, and this does not seem to bother governmental law- and policymakers (Solway 2002; Chebanne 2002, 2010, 2015). Even Vision 2016, put together by the Botswanan government's presidential task group in 1997, has legal limitations when it affirms a nation that is equitable, democratic, prosperous, educated, and informed (Botswana Government 1994, 1998), but it has not managed to give a voice to the socially- and economically-marginalised. The question that immediately arises is whether these people can develop their languages on their own as other marginalised communities are capable of doing (Chebanne and Nyati-Ramahobo 2003-2004). The following sub-sections provide evidence of the hurdles that Khoisan speech communities encounter in the development of their languages for literacy promotion in socio-cultural domains (Kamwendo, Jankie, and Chebanne 2009).

\subsection{State policies in culture and education}

State policies, it has been argued, cannot help develop Khoisan languages as they pursue a linguistic hegemony in favour of the official languages of English and Setswana (NyatiRamahobo 2002; Chebanne 2010). As such, in Botswana, the strategy to address linguistic and ethnic imbalance is non-existent. State developmental policies only go as far as the provision of food rations to poor communities through the remote area dweller programme, (see Botswana Government 2016; Thapelo 2002; Cassidy et al. 2001; Datta and Murray 1989). Even in the 
current situation, the government still affirms bold policy decisions that emphasise economic development rather than cultural and linguistic development by stating a shift from poverty reduction to poverty eradication (Botswana Government 2016: 221). The following quote by Cassidy et al. (2001: 13) illustrates this situation with the San which is not ameliorating:

The issue of education for [the] San goes beyond the availability of infrastructure [...] school attendance is significantly related to ethnic origin [and] part of the reason for this is that the teaching medium is in Setswana, a language that not all San know. Not all teachers are sympathetic to this disadvantage.

While it is possible that these programmes can improve livelihoods in Botswana by addressing poverty, the attainment of food, and economic security, there is no assurance that languages and cultures of the minority Khoisan communities will be guaranteed, nor that there will be development and preservation of these languages for generations to come. The sustainable livelihoods of the culturally-disadvantaged communities only succeed in drawing the Khoisan people closer to the mainline society which then assimilates them. In this state of assimilation, they lose their language and culture, and also their self-worth. Therefore, there seems to be a negation of social equity in the policy and practice thereof (Chebanne 2002, 2015; Nyati-Ramahobo 2002).

\subsection{How outside activism and advocacy disregard language issues}

Mphinyane (2002) faulted outside activism and advocacy for Khoisan communities by questioning their strategies which in the end did not empower or develop the members of these communities but instead created dependents. Some arguments provided in the foregoing sections have also identified some of the issues that come into play in the socio-political dynamics of the autochthonous groups. Historically, Khoisan issues have been raised and advanced by researchers (e.g. anthropologists, linguists, human rights activists, and outsider activists). Their emphasis has been on free development choice, equity, enjoyment of community rights, and ethnic identity (Saugestad 2001; Chebanne 2003, 2010). Now, outside activism and advocacy rely on anthropological and linguistic characterisation, and focus on divergent and sometimes competing interests. However, the lack of specific focus on language as a right means that the Khoisan will still remain linguistically impoverished (Batibo 2010; Chebanne 2010, 2015).

\subsection{San youth initiatives and their limitation in language and culture promotion}

It must be noted that the creation and maintenance of dynamic cultures are better exercised by the ethnic communities themselves (Batibo 2015; Chebanne 2010, 2015). This can be achieved through the involvement of communities via activities that promote their languages and culture. It is beneficial to pursue a programme for the promotion of identity, beliefs, and arts, as well as the desire to have them preserved through a national socio-economic system. However, language literacy is similarly very important (Chebanne 2002, 2015). It should be recalled that, since the country's independence in 1966, the national development policy of Botswana achieved negative ethno-linguistic and ethno-cultural developments which practically translated into two things: firstly, poverty in the cultural domain and the appeals of globalisation in the name of modernism and development (Nyati-Ramahobo 2002; Chebanne 2002); secondly, that poverty, marginalisation, and deprivation in the socio-economic domains became the bane of such communities (Jeffris 1997; Cassidy et al. 2001; Thapelo 2002). 
While the San youth are increasingly engaging in activities that affirm the right to self-identity, and the right to protection from the generalising and homogenising effects of the Botswana development policies, they are not yet articulating the right to their meaningful ethnic language and culture (Chebanne 2010, 2015). When they advocate for education and culture, it is within the confines and limits of community programs. The San youth, through their website sanyouthnetwork.com, have lofty goals and ideals, amongst which are to take part in research, consultation, debate, and the sharing of information in order to raise national and international awareness about San identity and their current reality. They also seek to build capacity and raise awareness on issues of indigenous identity. Furthermore, they want to provide a national voice for San youth, and ensure that they play an active role in debates and consultations on youth policy developments that affect the younger generations. Their emphasis is to advocate for and engage in lobbying for the health, and cultural and educational lifestyles of the San youth in particular. The goal for language and culture appears at a lower level of consideration, and is vaguely expressed as the maintenance, protection, and the development of San culture and language. However, the actions that are associated with this advocacy clearly show that they do not have the linguistic capacity to be agents of promotion and maintenance of vivid languages (San Youth Network 2018).

\section{Literacy as a basis for developing languages of the marginalised group}

The sources for these failures to promote indigenous languages are not new in research. UNESCO (1953) and many other educational organisations have untiringly advocated for mother-tongue education (Chebanne and Nyati-Ramahobo 2003-2004; Kamwendo et al. 2009). In their arguments, the school must accommodate the language of the child so as to create an environment, particularly at primary-school levels, that is close to the child's experience (Batibo 2010: 4). If this is not done, the child's learning process will be considerably compromised, and s/he will not have mastered his or her mother tongue fully by the time the new medium of instruction is introduced in grade 2 . This will substantially prevent the child from transferring prior knowledge to the new language setting (Nyati-Ramahobo 1998; Batibo 2010). Moreover, inadequate mastery of the medium of instruction will not facilitate proper cognitive and affective development in these young learners. These hurdles have been identified by Nyati-Ramahobo $(1987,1998)$. For minority language communities, these are major obstacles, and there is not a lot that the members of these communities can do on their own.

Batibo (2010: 4-5) also states that, apart from the work of non-governmental organisations (NGOs) and missionary activities, very little is happening for Khoisan languages in the effort to promote literacy in mother-tongue education in Botswana. Batibo provides factors that explain the failure of NGOs, missionary organisations, and communities to develop literacy, and thus promote Khoisan languages through mother-tongue education. These factors create hostile situations for or challenges with developing minority languages in a multilingual set-up (Batibo 2005, 2009). The first is State policy, with a restrictive language-in-education policy which favours the official languages of Setswana and English. The fear that multilingualism will promote ethnic tension and competition that results in division seems to be a fundamental hurdle to multilingualism in Botswana. The pedagogical factors that Batibo (2010: 5) identifies include teacher training in minority languages, material production, and lack of codification of some of these languages. While there are practical orthographies for a number of Khoe languages which have been quite successful (the Khwe orthography implemented in 2000 is used by the communities when, for example, creating booklets, and the Naro orthography of 1998 (Visser 
1998) is used for Bible translation), many of the Khoisan languages have no practical orthography designed for their literacy (Chebanne 2010, 2015). Economic forces of globalisation and international dynamics - which sway many parents and governments in their preference for education and literacy in languages of wider communication, such as English -also seem to have played a determining role in the neglect of minority languages such as those of the Khoisan.

The critical themes of literacy and the role thereof in language promotion and development in Botswana have been raised by Kamwendo et al. (2009). Literacy is critical in the development of a community, and constitutes the best method of empowerment (Youngman 1997). Literate speech communities can better advocate for their rights and develop their languages independently (Hasselbring 1999; Nyati-Ramahobo 2002; UNESCO 1996). Chebanne and NyatiRamahobo (2003-2004) demonstrate how language development empowered the Wayeyi and Kalanga communities in Botswana. For Khoisan languages, the Naro language literacy development effort, driven by the Bible translation project in D'kar in the Ghanzi District, has amply demonstrated how a Khoisan language can be a language of literacy (Visser 1998). The Naro experience is interesting from a social and economic perspective, as advocacy needs to be done with effective involvement of the speech community, and a concrete project needs to be undertaken to apply these literacy skills. However, for the rest of the Khoisan language communities, no such resources nor language development projects are available to them. The general prognosis, as stated by Brenzinger (2003: 59-60) is that, "even though heritage languages may still be spoken and will survive at least in the immediate future, the speakers will ultimately lose their specific concepts through assimilation to the few remaining world concept patterns".

Consequently, because of their poverty and lack of linguistic and cultural resources, the marginalised communities do not succeed in maintaining their languages. Chebanne and NyatiRamahobo (2003-2004) argued that Botswana should seriously consider other models of literacy development where communities are facilitated to implement literacy projects in local languages. Nyati-Ramahobo (1998) also emphasised the need to infuse language and culture into the curriculum in order to empower learners and teachers. Self-worth and -confidence derive from the sentiment that one's language is important, and that one can participate meaningfully in the development of one's language (Hasselbring 1999; Batibo 2009). African languages in Basic Education have also been reported to be a solid foundation for literacy development in Africa (Legère 1996), and Botswana could democratise its society more by introducing this right to education at early stages of literacy acquisition.

The current situation of the San people calls for action if they should be facilitated to overcome their socio-economic and socio-political hurdles. What follows below is a list of eight of these actions /recommendations that we believe could prove beneficial for the revitalisation and development of Khoisan languages.

(a) The government should promote the use of local languages in pre-schools, primary schools, and in informal education.

(b) Linguistic researchers should make more of an effort to contribute to Khoisan language research, and the development of orthography, grammars, and dictionaries. They should also arrange workshops for literate San youth where literacy skills could be transferred from Setswana and English into Khoisan languages so as to build literary capacity among the Khoisan. 
(c) The San youth activities should concentrate on organising cultural activities that foster language use and performance, such as in songs and dances.

(d) The San youth networks should work with community organisations and relevant government agencies to promote their languages and cultures.

(e) Stakeholders should create Khoisan networks in the region, and link up linguisticallyrelated communities for mutual support and capacity development in language and orthography in the documentation of their indigenous knowledge.

(f) The San communities should establish literacy classes for children and adults.

(g) Communities should work with government agencies to initiate cultural tourism and cultural industry.

(h) The San communities should link up with international indigenous peoples' advocacy groups to promote awareness and support of San identity and pride in language use.

\section{Conclusion}

The acclaimed development agenda of Botswana does not address the fundamental issues of the Botswanan San, namely self-determination of culture and language matters, land resource management, and respect of separate ethnic grouping to actualise cultural and linguistic identity, and indeed free choice for economic and social development. The "one size fits all" development approach has never been a solution to the plight of indigenous peoples. Different ethnic groups do not have equal means to engage development. The hackneyed chant of equality, without equity, has never succeeded in preserving indigenous peoples. The inappropriate policies employed to effectively homogenise the Botswana society to build a single monolithic ethnic identity are a source of San languages and culture endangerment. All of these approaches do not remove the Khoisan from economic and moral poverty, thereby diminishing the significance of their existence as a people (Cassidy et al. 2001; Jeffris 1997).

As stated in the discussion, there is also a need for the government to ratify all UN charters relative to indigenous and autochthonous communities, and the issues that concern their well-being and their future, especially in the context of globalisation which, as it has been repeatedly said, will present these communities with the dangers of extinction (Chebanne 2002; UNESCO 1953, 1996). As soon as Botswana puts mechanisms in place for the survival of its Khoe and San communities' languages and cultures, it will then have made itself an equitable and caring nation, according to Vision 2016. Otherwise, the Khoisan in Botswana, who are poor and lack any recourse and resources, are fighting a hostile battle (Batibo 2009, 2010). Botswana has no gain in upholding assimilating hegemony in matters of language and culture. Maintaining such a policy means killing other languages and cultures. Affirming equality without equity in the provision of socio-cultural and socio-economic amenities does not guarantee the maintenance of San lives nor their dynamic languages and cultures. Botswana must ratify the International Labour Organization Convention (No. 169) concerning Indigenous and Tribal Peoples as this forms a basis to engage objectively in the debate of their human rights, and their free choice in developmental policies. 


\section{References}

Barnard, A. 1988. Cultural identity, ethnicity and marginalisation among the Bushmen of Southern Africa. In R. Vossen (ed.) New Perspectives on the Study of Khoisan (Quellen zur Khoisan-Forschung, Vol. 7). Hamburg: Helmut Buske Verlag. pp. 7-27.

Barume, A.K. 2000. Heading Towards Extinction? Indigenous Rights in Africa: The Case of the Kahuzi-Biega National Park, Democratic Republic of Congo. Document No. 101, Copenhagen: International Work Group for Indigenous Affairs (IWGIA). https://doi.org/10.3366/afr.2002.72.1.172

Batibo, H.M. 2005. Language Decline and Death in Africa: Causes, Consequences and Challenges. Clevedon: Multilingual Matters. https://doi.org/10.21832/9781853598104

Batibo, H.M. 2009. Transmitting local and indigenous knowledge in a diminishing bio-cultural environment: The case of Botswana. In P. Bates, M. Chiba, S. Kube and D. Nakashima (eds.) Learning and Knowledge in Indigenous Societies Today. Paris: UNESCO Press. pp. 87-94.

Batibo, H.M. 2010. Fighting a losing battle? Assessing the impact of mother-tongue education advocacy in a hostile environment. Unpublished Keynote address delivered at the Plurilingual Education Conference. 19-20 February 2010, School of Oriental and African Studies, London.

Batibo, H.M. 2015. An ideal language policy for an inclusive and sustainable development in Africa. In P. Skoeld, M. Sondstroem and M. Bolaane (eds.) Under the Same Sun: Parallel Issues and Challenges for the San and Sami Peoples. Umea: Umea University Press. pp. 7178.

Brenzinger, M. 2003. Language and conceptual diversity under threat: Language endangerment on the African continent. In J. Vielberth and G. Drexter (eds.) Linguistic and Cultural Identity and International Communication: Maintaining Language Diversity in the Face of Globalization. Saarbruken: AQ Verlag. pp. 57-77.

Cassidy, L., K. Good, I.N. Mazonde, and R. Rivers. 2001. An Assessment of the Status of the San/Basarwa in Botswana. Regional Assessment of the Status of the San in Southern Africa. Report Series No. 3 of 5. Windhoek: Legal Assistance Centre.

Chebanne, A. 2002. Minority languages and minority people: Issues on linguistic, cultural and ethnic death in Botswana. In I.N. Mazonde (ed.) Minorities in the Millennium: Perspectives from Botswana. Gaborone: Lentswe la Lesedi and Lightbooks Publishers. pp. 47-58.

Chebanne, A. 2003. Autochthonous groups of the Khoe and the San and the government: Why a dialogue of the deaf? Unpublished paper presented at the International Khoe and San Conference, 10-12 September 2003, University of Botswana, Gaborone.

Chebanne, A. 2010. The Khoisan in Botswana - Can multicultural discourses redeem them? Journal of Multicultural Discourses 57-105. https://doi.org/10.1080/17447141003639801 
Chebanne, A. 2015. Writing Khoisan: Harmonized orthographies for development of underresearched and marginalized languages - The case of Cua, Kua, and Tsua dialect continuum of Botswana. Language Policy 15(3): 277-297. https://doi.org/10.1007/s10993-015-9371-1

Chebanne, A. and L. Nyati-Ramahobo. 2003-2004. The development of minority languages for adult literacy in Botswana: Towards cultural diversity. Southern Africa Review of Education (SARE) with Education with Production 9(10): 75-93.

Datta, K. and A. Murray. 1989. The rights of minorities and subject peoples in Botswana: A historical evaluation. In J. Holm and P. Molutsi (eds.) Democracy in Botswana. Gaborone: Macmillan. pp. 58-73.

Dowson, T.A. and D. Lewis-Williams (eds.) 1994. Contested Images - Diversity in Southern Africa Rock Art Research. Johannesburg: Witwatersrand University Press.

Eide, B. 2000. Prevention of Discrimination Against and the Protection of Minorities. Working Paper on the Relationship Between the Rights of Persons Belonging to Minorities and Those of Indigenous Peoples. Commission on Human Rights, Sub-Commission for the Promotion and protection of Human Rights - Working Group on Minorities, Seventh Session. UN Digital Library. E/CN.4/Sub.2/2000/10. https://doi.org/10.2307/762426

Güldemann, T. 2014. Khoisan linguistic classification today. In T. Güldemann and A-M. Fehn (eds.) Beyond 'Khoisan': Historical Relations in the Kalahari Basin. Amsterdam: John Benjamins. pp. 1-41. https://doi.org/10.1075/cilt.330.01gul

Hasselbring, S. 1999. Literacy among those who speak Tswana as a second language. In Statistics Botswana (eds.) The First National Literacy Survey in Botswana - 1993. Dissemination Seminar. Report of the Proceedings. Gaborone: Central Statistics Office and the Department of Non-Formal Education. pp 54-66.

Jeffris, K. 1997. Poverty in Botswana. In D. Nteta and J. Hermans (eds.) Poverty and Plenty: The Botswana Experience. Gaborone: The Botswana Society. pp. 33-59.

Kamwendo, G., D. Jankie and A. Chebanne. (eds.) 2009. Multilingualism in Education and Communities in Southern Africa. Gaborone: UB Trømso Collaborative Programme for San Research and Capacity Building.

Legère, K. 1996. African Languages in Basic Education. Windhoek: Gamsberg Macmillan.

Mazonde, I.N. (ed.) 2002. Minorities in the Millennium: Perspectives from Botswana. Gaborone: Lightbooks.

Mokhtār, G. (ed.) 1990. General History of Africa II: Ancient Civilizations of Africa. Berkeley: University of California Press.

Mphinyane, S.T. 2002. Power and powerlessness: When support becomes overbearing - The case of outsider activism on the settlement issue of the Basarwa of the Central Kalahari Game Reserve. PULA: Botswana Journal of African Studies 16(2): 76-85. 
Nyati-Ramahobo, L. 1987. Minority language users in a multilingual society and early educational hurdles: A case of Botswana. PULA: Botswana Journal of African Studies 8(1): 90-114.

Nyati-Ramahobo, L. 1998. Language, culture and learning: The missing link in teacher education. In C.D. Yandila, P. Moanakwena, F.R. O'Mara, A.M. Kakanda and J. Mensah (eds.) Improving Education Quality for Effective Learning: The Teacher's Dilemma. Gaborone: Ministry of Education. pp. 207-214.

Nyati-Ramahobo, L. 1999. The National Language - A Resource or a Problem: Implementation of the Language Policy in Botswana. Gaborone: Pula Press.

Nyati-Ramahobo, L. 2002. Ethnic identity and nationhood in Botswana. In I. Mazonde (ed.) Minority in the Millennium: Perspectives from Botswana. Gaborone: Lightbooks. pp. 17-28.

Presidential Task Group. 1997. Vision 2016: Towards Prosperity for All. Gaborone: Vision 2016 Secretariat.

Republic of Botswana. 1987. Constitution of Botswana Act 22 Article 61 (d). Gaborone: Government Publisher.

Republic of Botswana. 1994. Government Paper No.2 of 1994. The Revised National Policy on Education 1994. Gaborone: Republic of Botswana.

Republic of Botswana. 1998. Vision 2016: Report on the Long Term Vision for Botswana. Presidential Commission on the Long Term Vision. Gaborone: Government Publisher.

Republic of Botswana. 2016. National Development plan 11. Gaborone: Government Publisher.

San Youth Network. 2018. Available online: https://sanyouthnetwork.wixsite.com/website (Accessed 2 May 2018).

Saugestad, S. 2001. The Inconvenient Indigenous: Remote Area Development in Botswana, Donor Assistance, and the First People of the Kalahari. Uppsala: Nordic Africa Institute. https://doi.org/10.2979/aft.2004.51.1.133

Shillington, K. 1989. History of Africa. London: Macmillan.

Silberbauer, G. 1981. Hunter and Habitat in the Central Kalahari Desert. Cambridge: Cambridge University Press. https://doi.org/10.1002/pad.4230030113

Solway, J.S. 2002. Navigating the "neutral" state: Minority rights in Botswana. Journal of Southern African Studies 28(2): 711-729. https://doi.org/10.1080/0305707022000043485

Thapelo, T.D. 2002. Markets and social exclusion: Postcolony and San deprivation in Botswana. PULA: Botswana Journal of African Studies 16(2): 135-146. 
UNESCO. 1953. The Use of Vernacular Languages in Education. Report of the UNESCO meeting of specialists. Paris: UNESCO. https://doi.org/10.1515/9783110805376.688

UNESCO. 1996. Learning: The Treasure Within. Report to UNESCO by the International Commission on Education for the $21^{\text {st }}$ Century. Paris: UNESCO. https://doi.org/10.7788/ijbe.1996.24.1.253

UNESCO World Commission on Culture and Development. 1995. Our Creative Diversity. Paris: UNESCO.

United Nations (CERD). 2002. Consideration of reports submitted by States parties under Article 9 of the Convention. International Convention on the Elimination of all Forms of Racial Discrimination. Geneva: UN. https://doi.org/10.18356/4023c18c-en

Visser, H. 1998. Language and Cultural Empowerment of the Khoesan People: The Naro Experience. Public lecture at the University of Botswana.

Vossen, R. 1988. Patterns of Language Knowledge and Language Use in Ngamiland, Botswana. Bayreuth: Bayreuth University.

Youngman, F. 1997. Adult literacy and social development in Botswana. Mosenodi 5(2): 15-27. 